\title{
Strategy Research of International Trade Financing of Small and Medium Foreign Trade Enterprises in Heilongjiang Province
}

\author{
Sunying ${ }^{1}$, Wangxu ${ }^{1}$, Qianhong ${ }^{1}$ \\ Economy Management Institute \\ Northeast Forestry University \\ Harbin, China \\ sunyinglaoshi@163.com \\ wangyuehan1984@163.com \\ mnnqian@163.com
}

\begin{abstract}
With the expansion of foreign trade scale and the increasing of demand for capital of enterprise in Heilongjiang Province, we advance new demand of trade financing. However, compared to coastal developed cities, the trade financing in Heilongjiang province still has a long way to go. Because of enterprises' having not enough knowledge of trade financing, bank's lacking of creativity and imperfection of credit system, the foreign trade enterprises in Heilongjiang province have the problems of effective demand insufficiency and the obstruction of supply in trade financing. Based on the background of increasingly internationalization of financing and foreign trade enterprises' imperious demands for funds, this paper started from the current situation of trade financing of foreign trade enterprises of Heilongiiang province, explored the problems and obstacles existed in the trade financing cooperation between foreign trade enterprises and banks, proposed the conception about trade financing mode selection strategy and new enterprises' credit system for the first time. We pointed out that the bank's trade finance products and their pricing should be adapted to the actual needs of foreign trade enterprises, and stressed that the commercial banks should strengthen the risk control of trade financing and so on, in order to comprehensively promote foreign trade and economic sustainable development of Heilongjiang Province.
\end{abstract}

Key Words-foreign trade enterprises; trade financing; credit system; financial innovation; Risk Control

In recent years, the Heilongjiang Province international trade development is increasing, trade financing is also vigorously developing. For banks, to develop trade financing not only can absorb foreign trade enterprises' international settlement, but also lead the banks' other comprehensive trade development directly. For the enterprises, because trade financing thinks highly of the trade background's verification and both transaction parties' strength and the prestige, compared to the traditional loan business, the small and medium foreign trade enterprises are easier to obtain the fund from banks for solving shortage of capital. But in practice, because the society has not really established the perfect credit system of the small and medium enterprises, bank still have many misgivings to the small and medium enterprises when they enlarge trade financing service, even appears "unwilling to provide loans". At the same time, because the small and medium trade enterprise itself is not familiar to the new financing business and has the barriers in the application, this enormously hinders communal development of the bank and the small and medium foreign trade enterprise, and causes the banks' anticipated profit to be reduced and the loss of the good development opportunity. Therefore, we must base on two sides of the bank and the enterprise to transform the bilateral idea. The banks must try to improve their professional ability and develop the financial innovation business increasingly, overcome "unwilling to provide loans", be positive to provide the financing services which adapt to needs of the small and medium foreign trade enterprise. The small and medium foreign trade enterprise should strengthen the competition strength virtually, enhance the credit, change tradition idea as soon as possible and be in time to be familiar to and apply a lot more new financing business. This may solve the problems of "want to do but cannot do, can do but be able to do, be able to do but not elect" that the bank and the enterprise frequently meet when they do trade financing business. In addition, looking from the social environment aspect, various levels of the government must provide kinds of preferential policy to support and construct the new enterprise credit system, and the government should take the practical and effective measures to solve kinds of problems in order to realize the Heilongjiang Province trade and the economical sustainable development.

\section{STATUS OF INTERNATIONAL TRADE FINANCING OF SMALLAND MEDIUM FOREIGN TRADE ENTERPRISE IN HEILONGJIANG PROVINCE}

The trade financing in China began in the 1980s. In 1986, the China-Bank manages the bill purchased business in mainland firstly drawing on the experience of Hong Kong. In 1987, international factoring business entered into our market. In 1995, our country firstly developed forfaiting business. At the same time, the commercial bank in Heilongjiang Province also started to handle trade financing business of which the business volume are few at first that obtain much more development until the beginning of 21 st century. In 2005 , the branch China-Bank and the branch agricultural bank in Heilongjiang Province are in the first place and second place respectively in the amount of international settlement and trade financing business in Heilongjiang Province ${ }^{[1]}$. In 2006, the 
China-Bank in Suifen River also succeeded handled the first trade financing business. With the fast development of Heilongjiang Province's foreign trade, the demanding market of Heilongjiang Province's trade financing will also expand increasingly.

In the first half of 2008, the total amount of import and export of Heilongjiang Province adds up to 8.54 billion dollars, compared with growth of $23.5 \%$ over the same period in 2007 . Of the total amount, export accounts for 5.61 billion dollars, growing $28.1 \%$ which is higher $6.2 \%$ than the national export growth rate, and import accounts for 2.93 billion dollars, growing $15.5 \%$ over the same period. Of which mechanical and electrical products and high-paying technology products achieve growth. From January to September in 2008, total exports of electromechanical products in Heilongjiang Province add up to 3.14 billion dollars, accounting for $21.3 \%$ of the province's import and export of plant ${ }^{[2]}$. The increased amount of business of foreign trade enterprises especially import and export of electromechanical and high-tech enterprises and the demand of deferred payment on buyer's market lead to a great demand for capital of foreign trade enterprises increasingly. According to foreign trade enterprise storage information statistics of China Association of Foreign Trade and Economic Cooperation Enterprises, at present, there are more than 4,000 foreign trade enterprises in Heilongjiang Province which use internal financing, debt capital financing and bank loans, some of which large foreign trade enterprises use listed financing. However, most small and medium foreign trade enterprises' financing capital is limit, and it is difficult to issue commercial paper and bonds, so they usually choose loan financing. However, because of a higher threshold for bank loans and the long processing time, it can not resolve foreign trade enterprises short term requirements of funds. While the trade financing can provide short or long financing convenience which is related with settlement during the Bank's operation of international settlements. In the context of a real-trade, trade financing has much more advantages of financing facilities than loans. Therefore, the demands for capital of small and medium enterprises make trade financing have great potential market. However, the development of trade financing business in Heilongjiang Province and the market demand are imbalanced and there are still numerous obstacles and problems to be solved.

\section{PROBLEMS AND REASONS OF TRADE FINANCING OF SMALL AND MEDIUM FOREIGN TRADE ENTERPRISES IN HEILONGJIANG PROVINCE}

By research and the actual inspection of some banks and enterprises in Heilongjiang Province, we see that the development of trade financing of small and medium foreign trade enterprises in Heilongjiang Province is not mature enough, there are still many problems to be solved.

\section{A. The effective demand of trade financing business in Heilongjiang Province and the market potential are imbalanced}

The import and export value of small and medium enterprise accounts for $70 \%$ of the gross import and export value in Heilongiiang Province. Therefore, the management's level of small and medium enterprise affects the foreign trade development in Heilongjiang Province. According to the related department investigation, the finance of above $80 \%$ of county small and medium enterprise in the Heilongjiang Province is insufficient, above $90 \%$ of which are in credit blank $^{[3]}$.

In the sampled investigation of non-public ownership system Industrial enterprise in Heilongjiang Province, there are above $95 \%$ of small and medium enterprise among 2121 investigated households, all of which there are $92.6 \%$ of enterprises thinking that the loans are not easy to have ${ }^{[4]}$. This indicated that it is very difficult for the small and medium enterprise obtain capital by the traditional loan way. Trade financing takes the single trade as a background and does not think highly of enterprise's financial situation and the profession status, the admittance threshold is low and be appropriate for character of the low intelligence of small and medium foreign trade enterprise that be in favor for the small Foreign trade enterprise to obtain the fund in a short time. But according to investigation and study result of some branch bank in Heilongjiang Province, in trade financing business of this bank, business volume of small and medium foreign trade enterprises account for less than $10 \%$ of total quantity. In developed country, trade financing has already become the financing important tool for small and medium foreign trade enterprises. The Heilongjiang Province trade's fast development will also make trade financing have the broad market. However, at present, many small and medium foreign trade enterprises in Heilongjiang Province do not know and be familiar with the trade financing business, and the banks make insufficient propaganda, this will cause the small and medium foreign trade enterprise not to choose this kind of financing way. Therefore, trade financing in Heilongjiang Province has problems of big the market potential but the insufficient effective demand.

\section{B. Trade financing structure of foreign trade enterprise is single}

The trade financing way of small and medium foreign trade enterprise in Heilongjiang Province are mainly by traditional ways of import and export documentary, packing credit, and mostly taking the letter of credit as settlement way. The new trade financing businesses such as international factoring, forfaiting as well as structured trade finance are really few. For example, the amounts of foreign trade enterprises using international factoring for finance is less than $1 / 3$ of investigated enterprises. The main reason of the single financing structure of the small and medium foreign trade enterprise in Heilongjiang Province is the supply is not smooth. Because in Heilongjiang Province, the bank lacks of high quality talent transformed from the trade financing researches to the application, the individual bank was still blank in the new trade financing that be unable to meet the needs of enterprises' trade financing. Also, the new trade financing drawing from their banks of other provinces are 
actually empty in the theory and stagnated in the practice, therefore the expense to these business are often high and the examination procedure is complex, time-consuming is long. From the security and the financing convenience consideration, the small and medium foreign trade enterprise subsequently does not bring new non-skilled trade financing business into their banks. All of these reasons caused the single trade financing structure problem.

\section{Lacking of the trade financing risk cognition and the guard experience}

Trade financing exist trade risks, operation risk, bank and import and export enterprise credit risk and so on. Because the bank lacks the risk cognition and control ability, the operation cannot meet the standard and in time for warning and controlling to the risk, in addition, the foreign trade enterprise knows little about the trade financing, the small Foreign trade enterprises' credit level is not high, cause the bank and enterprise are lack of the cooperation confidence. Then this causes trade financing not to obtain the proper development in Heilongjiang Province.

\section{The credit mechanism which trade financing depends on is not perfect}

The development of trade financing mainly based on commercial credit or bank credit. Therefore, the imperfect credit mechanism can cause the trade financing to lack the safeguard. Firstly, looking from the credit mechanism's exterior restraint environment, the credit mechanism's exterior restraint environment of Heilongjiang Province is mainly decided by the laws and regulations consummation, our country's finance legislation lags obviously in the financial business's development that caused both sides of the right and voluntary having no laws to depend on when there is a dispute and enlarged the possibility of losing credit of voluntary side. Secondly, the enterprise information's opacity in Heilongjiang Province caused the information between the bank and the enterprise is asymmetrical, in addition the existence of lack of enterprise morals and the opportunism ideas caused the bank having credit risks. Finally, the trade financing in Heilongjiang Province has continued to use the credit appraisal system of general credit business, therefore the admittance threshold is high and it has hindered the trade financing development..

\section{COUNTERMEASURE AND SUGGESTION TO TRADE FINANCING OF SMALL AND MEDIUM FOREIGN TRADE ENTERPRISE IN HEILONGJIANG PROVINCE}

\section{A. The government should strengthen the policy support}

Government's policy support will provide a stable environment for foreign trade finance and promote small and medium enterprises to obtain finance. Premier Wen Jiabao proposed at the second meeting of the two: to take effective measures to support SME's development, and increase the central government's SME development funds from 3.9 billion to 9.6 billion. The Central Committee also emphasized the need of vigorous reform of the financial system, to give full play to trade financing's important role for SME development.
Relevant government departments of Heilongjiang Province should be in accordance with the actual needs of small and medium foreign trade enterprises to increase financial support; to encourage banking and financial innovation, and reward the reasonable and good economic returns of trade financing innovation; to be deal well with relationship between financial innovation and financial supervision. The relevant government departments should bear the responsibility in the maintenance of financial stability and security and play well of its supervisory role.

\section{B. Banks and enterprises cooperate to improve the application of trade financing}

Firstly, banks should increase the supply capacity of trade finance products. Bank marketing department should be more communication with the foreign trade enterprises and combine internal staff of work experience with the idea of foreign trade enterprises. To base on this, the R \& D departments should combine trade finance products, optimize the cost structure, such as the portfolio of Forfaiting and export seller's credit, portfolio of export credit insurance and international syndicated loan to reduce the financing costs ${ }^{[5]}$, or make a new trade financing package. At the same time, we should strengthen ties with major trading partners such as Russia, Japan, the National Bank of cooperation, join in the development of new trade finance tools. Secondly, the foreign trade enterprises should be based on the principle of cost savings, strengthen the rational use of trade financing. After understanding the characteristics of a variety of trade financing, we may choose the means of financing according to the import and export products' production cycle, the nature of products, import and export volume, firm size, income and other factors which is suitable to the enterprise. Finally, both sides of the banks and the enterprises may sign long-term financing agreement that can supply and improve trade finance business in the cooperation in order to increase bank profits while serve well for foreign trade enterprises of the trade finance business.

\section{Banks must strengthen their ability to control the trade finance risk}

At present, the trade financing in Heilongjiang Province is mostly in the condition of credit letter. Therefore, banks should regulate letter of credit operations and management in the risk prevention. Secondly, we should establish early warning mechanism. Banks may coordinate with foreign banks to pay close attention to the country's political and economic situation, credit records and market conditions which import and export enterprises belong to, to effectively control the country risk. Thirdly, we should evaluate trade financing by combining the real background of single trade with the history of corporate credit conditions, taking a sum of self-discharge characteristics of trade finance and enterprises the ability of enterprise of trade into consideration ${ }^{[6]}$, to have a special assessment of customer's export and import financing, to establish new credit evaluation system. Finally, we can create risk transfer strategy to reduce risk through third-party guarantees, disposal of collateral or corporation with 
experienced foreign banks to diversify and transfer credit risk. Only banks improve risk control capability, the volume of trade finance business will be increased.

\section{To establish enterprise credit system in Heilongjiang Province}

The establishment and improvement of enterprise credit system is a key to resolve the bad external environment of trade financing. The improvement of the enterprise credit favors the bank and enterprise cooperation. For the Foreign trade enterprise, this means more and more enterprises obtains the admittance pass of the bank's trade financing service that impel trade financing business of small and medium foreign trade enterprise to increase enormously. Therefore, this article plans to construct the enterprise credit system in the foundation of entire province small and medium enterprise credit status pilot work. The enterprise credit system's goal is to promote the enterprise transaction to be achieved and the realization of financing. Profits from research results of the establishment of society credit system, we plan to construct the basic credit system of enterprise in Heilongjiang Province. See Figure 3-1.

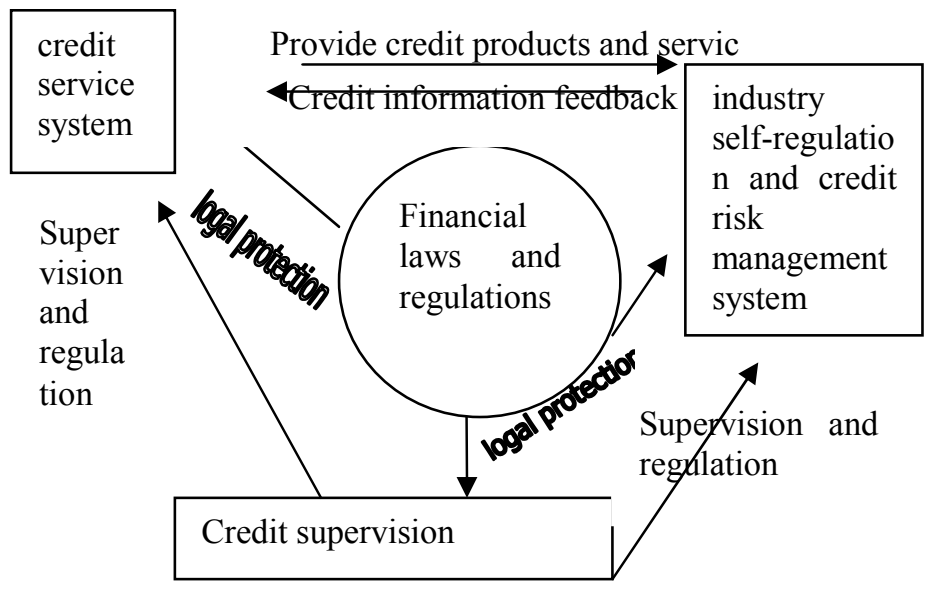

Figure 3-1 Frame chart of enterprise credit system in Heilongjiang Province

Figure 3-1 had indicated four mutual restricted relations, the perfection of the finance laws and regulations and the credit supervision system may provide fair, safe, stable external environment for the establishment of enterprise credit system in Heilongjiang Province. The establishment of credit services structure may provides the credit product and the service for the enterprise or the profession, such as credit investigation, rating, guarantee and so on. At the same time, the latter may provide the credit information feedback for the former that favors the credit product related transaction. However, entire credit system's operation must take in the good operational mechanism as a premise, this needs to establish kinds of mechanism premised of protection of country secret and the enterprise's commercial secret to raise the information's ventilated level and promote the demand and the supply for credit product, in order to improve trade financing's exterior credit environment.

The small and medium foreign trade enterprises in Heilongjiang Province mostly need the fund, but they are also most under the financing requirement. We know that lack of fund make the enterprises not be able to develop, no developing will make enterprise not be able to obtain the loan from the bank. This article based on research of the small and medium foreign trade enterprises' trade financing come to the following conclusion: 1 )Small and medium foreign trade enterprise has made the great contribution to Heilongjiang Province, but the foreign trade enterprises' fund shortage has become the primary factor that restricts its development. However, because the trade financing has the high benefit and low cost characteristic that is more suitable for financing compared to other financing way. 2 )The small and medium foreign trade enterprises need to learn to select the different trade financing way reasonably according to their own business demand. At the same time, small and medium foreign trade enterprise should carry on the cost analysis by the smallest cost gain greatest income principle when choosing financing way, and must fully understand and circumvent all kinds of potential risk of trade financing to avoid losing. 3) To promote trade financing development, we must construct enterprise credit system of the Heilongjiang Province. This is the key to solve the problem of imperfect external environment of trade financing. In the condition of unceasingly perfect of enterprise credit system, small and medium foreign trade enterprise should be in full understanding trade financing business's superiority and significance for enterprise and have a more widespread application of trade financing business. The bank will also unceasingly innovate business according to the enterprise's demand. This will improve the supply and demand asymmetrical condition of trade financing in Heilongjiang Province enormously and resolve the realistic problem of small and medium foreign trade enterprises' trade financing, facilitate the bank and the small and medium foreign trade enterprise's communal development, and then comprehensively impel the foreign trade and the economical sustainable development in Heilongjiang Province.

\section{REFERENCE}

[1] Heilongjiang news net http://news.xinhuanet.com/2006russia/2006-06/28/content_4759700.htm

[2] Harbin Customs materials in 2008

http://harbin.customs.gov.cn/publish/portal118/tab1731/module3795/info 130469.htm

[3] Heilongjiang Province's non-private economy development report in 2008. Heilongjiang Province small and medium-sized enterprise bureau

[4] Heilongjiang Province statistics bureau labor hands over place at the end of 2005 to count.

[5] Guo Shoufeng. Our country's innovation's way chioces of international trade financing [J]. finance economy, 2008(24), pp. 33-34

[6] Jialei. Discusses of our country Commercial bank's trade financing innovation [D]. Shanghai Foreign language University, 2006,12:13 - 1 